$\xi_{p-m}$

\title{
Potential anti-diabetic property of the aqueous extract of the leaves of Saba senegalensis Pichon (apocynaceae) in mice
}

\author{
Dosso Mamadou ${ }^{1 *}$, Coulibaly Adama ${ }^{1}$, Coulibaly Ousmane ${ }^{2}$, Soro Doudjo ${ }^{2}$, N'guessan Jean David ${ }^{3}$ \\ ${ }^{1}$ Department of Biochemistry-Genetics, Péléforo Gon Coulibaly University, BP 1328 Korhogo, Côte d'Ivoire (Ivory Coast) \\ ${ }^{2}$ UMRI Food, Chemical and Environmental Process Sciences, Félix Houphouët-Boigny National Polytechnic \\ Institute (INP-HB), BP 1313 Yamoussoukro, Côte d'Ivoire \\ ${ }^{3}$ Laboratory Pharmacodynamics Biochemistry, Department of Biosciences, Félix Houphouët-Boigny \\ University 22 BP 582 Abidjan 22 Côte d'Ivoire \\ *Corresponding author E-mail: coatcha1012@gmail.com
}

\begin{abstract}
This study made it possible to demonstrate that Saba senegalensis has hypoglycemic and anti-hyperglyvemic effects in mice. The aqueous extract of Saba senegalensis from 75 to $250 \mathrm{mg} / \mathrm{Kg}$ bw causes a dose-dependent hypoglycemia ranging from 4.84 to $34.62 \%$ (p <0.010.05), in normoglycemic mice, 60 minutes after treatment. The Glucose-Induced Hyperglycemia Orally (OPGH) test showed that in the presence of Saba senegalensis aqueous extract at a concentration between 75 and $250 \mathrm{mg} / \mathrm{Kg}$ bw, the glucose-induced hyperglycemic peak $(3 \mathrm{~g} / \mathrm{Kg} \mathrm{bw})$ is reduced from 26.49 to $71.77 \%$ ( $\mathrm{p}<0.01-0.05)$, 30 minutes after treatment. Oral administration of the aqueous extract of this plant in doses up to $5000 \mathrm{mg} / \mathrm{Kg}$ bw resulted in no deaths in mice during two weeks of observation.
\end{abstract}

Keywords: Saba Senegalensis; Antidiabetic; Hypoglycemic; Antihyperglycemic; Mouse.

\section{Introduction}

Diabetes is a metabolic disease, characterized by chronic hyperglycemia (American Diabetes Association 2002). There are mainly two types of diabetes, 85-90\% of which are type II (Dénoue et al. 2016, Kambouche et al., 2011).

Unlike Type I, Type II is non-insulin-dependent. Its treatment is based on oral antidiabetic drugs, some of which cause prolonged hypoglycemia that is just as severe as their complications. These life-long treatments are also expensive, requiring significant resources for their management. Secondary resistance, hypersensitivity and intolerance reactions have also been reported in some patients undergoing antidiabetic treatment (Marles et al., 1994).

For these reasons, new, less expensive molecules with fewer side effects are to be sought. In order to solve their health problems, the African population has chosen medicinal plants, an undeniable source of bioactive molecules (Kambouche et al., 2011, N'Doua et al., 2015). To date, many of these plants have been listed and are the subject of active traditional use (Dénoue et al., 2016). Saba senegalensis, with multiple therapeutic virtues, is one of them; it has large and strong woody liana, with white latex. Saba senegalensis of the family Apocynaceae, which requires a lot of sunlight, is native to tropical Africa (Arbonnier, 2002). It is a Sudanian and Guinean plant, occurring from Senegal to Nigeria via Côte d'Ivoire, Mali and Burkina Faso (Sarr et al., 2018). In traditional medicine, this plant is used against constipation, scleroderma, parasitic infections, headaches and food poisoning. It is also used in the treatment of urinary schistosomiasis and as an antiemetic (Eklu-Natey et al., 2012). Pharmacological data show that the leaves are anti-inflammatory, analgesic, antioxidant (Sarr et al., 2015) and antihelmintic (Magassouba et al., 2007, Traore et al., 2013, Boamponsem et al., 2013). The phytochemical study of the leaves indicates that its aqueous extract contains tannins, saponins and flavonoids (Sarr et al., 2015), chemical groups known for their hypoglycemic properties (Masunda et al., 2014, Kambouche et al., 2009).

Aided by this phytochemical content and in order to contribute to the pharmacological study of this plant for which little tangible scientific information is available to date, this study will evaluate:

- The hypoglycemic effects of the aqueous extract of the leaves of Saba senegalensis in normo-glycemic mice; and.

- The antihyperglycemic agent in mice temporarily hyperglycemic by oral glucose administration (OPGH test).

\section{Materials and methods}

\subsection{Material}




\subsubsection{Vegetal material}

The leaves of Saba senegalensis (SAB) were harvested in December 2019 in Korhogo, a town north of Côte d'Ivoire. The plant was identified by the Botany Laboratory of the Biosciences School of the University Felix Houphouët Boigny from a herbarium of the National Center of Floristics. The leaves were dried in the shade between 25 and $28^{\circ} \mathrm{C}$, then crushed and reduced to a powder from which the aqueous extract was made.

\subsubsection{Animal material}

Mice of the species Mus musculus (Muridae) male and female weighing between 20 and 30 grams were used for the toxicological and pharmacological tests. Fed with granules supplied by the company IVOGRAIN, they were reared at an average temperature of $28^{\circ} \mathrm{C}$ with a relative humidity of 70\%, at the pet shop of Department of Biochemistry-Genetics, Péléforo Gon Coulibaly University of Côte d'Ivoire, (Korhogo, Côte d'Ivoire). The photoperiod is from 12/24 hours.

\subsubsection{Chemical product}

- Glibenclamide arrow: (SANOFI-AVENTS (France).

- $\quad \mathrm{D}(+)$ Glucose anhydrous: E. MERCK, Darmstadt (Germany).

- Nacl 0,9\%: Pharmivoirenouvelle (Yopougon industrial area; Abidjan-Côte d'Ivoire).

\subsection{Methods}

\subsubsection{Extraction}

Two hundred grams (200) of crushed leaves of Saba senegalensis are dried at a temperature of $27^{\circ} \mathrm{C}$. They are ground into powder. Two hundred (200) grams of powder are dissolved in four liters of distilled water. The mixture is macerated during 24 hours. The solution obtained is filtered using cotton wool and Wattman paper. The same operation is repeated. Distilled water is added to the pellet, mixed for 2 hours and filtered as well. The filtrates are collected in a flask and oven-dried at $40^{\circ} \mathrm{C}$. The resulting powder, perfectly soluble in water, is used as a crude extract of Saba senegalensis.

\subsubsection{Acute toxicity study by gavage}

For the study of the acute toxicity of the aqueous extract of Saba senegalensis, we have 60 Mus musculus mice (males and females) at our disposal. Randomly divided into 6 batches of 10 animals each ( 5 males and 5 females), 5 batches were given increasing doses of SAB aqueous extract, ranging from 100 to $5.10^{3} \mathrm{mg} / \mathrm{Kg}$ body weight (BW) orally with an intragastric tube. The control lot was treated with a saline solution of $\mathrm{Nacl}(0.9 \%)$. The number of dead mice was recorded after 30 minutes, two hours or even two weeks after administration. This study was performed 3 times.

\subsubsection{Evaluation of the hypoglycemic activity of the aqueous extract of Saba senegalensis in normo-glycemic mice}

We have 30 mice divided into 6 batches, each batch comprising 5 animals. After 12 hours of fasting, the initial blood sugar level of the mice is taken, then they are subjected to the different treatments as indicated below:

- Batch 1: represents that of the control mice receiving $0.5 \mathrm{ml}$ of distilled water

- Batch 2: mice treated with SAB aqueous extract at $75 \mathrm{mg} / \mathrm{Kg}$ bw.

- Batch 3: mice treated with $\mathrm{SAB}$ aqueous extract at $150 \mathrm{mg} / \mathrm{Kg}$ bw.

- Batch 4: mice treated with $\mathrm{SAB}$ aqueous extract at $200 \mathrm{mg} / \mathrm{Kg}$ bw.

- $\quad$ Batch 5: mice treated with $\mathrm{SAB}$ aqueous extract at $250 \mathrm{mg} / \mathrm{Kg}$ bw.

- Batch 6: mice treated with glibenclamide $10 \mathrm{mg} / \mathrm{Kg}$ bw.

After these different treatments, the animals' blood sugar levels are measured every 30 minutes for 2 hours. The blood glucose level was measured using an Accu- Check Active glucometer on blood taken from the tail of the mouse. The percentage change in blood glucose was calculated.

\subsubsection{Evaluation of the anti-hyperglycemic activity of the aqueous extract of Saba senegalensis in mice temporarily hyperglycemic (HGPO test)}

During this study, 30 male and female Mus musculus mice were divided into 6 batches of 5 animals each. These animals, after 12 hours fasting, were pre-treated with aqueous extract of Saba senegalensis or glibenclamide (positive control) and then subjected to temporary hyperglycaemia by oral administration of a glucose solution at a dose of $3 \mathrm{~g} / \mathrm{Kg}$ bw :

- $\quad$ Batch 1: control mice receiving glucose at $3 \mathrm{~g} / \mathrm{Kg}$ bw.

- Batch 2: mice treated with Saba senegalensis aqueous extract (SAB) at $75 \mathrm{mg} / \mathrm{Kg}$ bw, then glucose at $3 \mathrm{~g} / \mathrm{Kg}$ bw .

- Batch 3: mice treated with aqueous extract of Saba senegalensis at $150 \mathrm{mg} / \mathrm{Kg}$ bw, then glucose at $3 \mathrm{~g} / \mathrm{Kg} \mathrm{bw}$.

- Batch 4: mice treated with aqueous extract of Saba senegalensis at $200 \mathrm{mg} / \mathrm{Kg}$ bw, then glucose at $3 \mathrm{~g} / \mathrm{Kg} \mathrm{bw}$.

- Batch 5: mice treated with aqueous extract of Saba senegalensis at $250 \mathrm{mg} / \mathrm{Kg}$ bw, then glucose at $3 \mathrm{~g} / \mathrm{Kg} \mathrm{bw}$.

- $\quad$ Batch 6: mice treated with glibenclamide $10 \mathrm{mg} / \mathrm{Kg} \mathrm{PC}$, then glucose at $3 \mathrm{~g} / \mathrm{Kg}$ bw.

The blood glucose levels of the mice in each batch are measured, just before administration and after treatment, at 30-minute intervals for 2 hours. The percentage change in blood glucose levels is calculated.

\subsection{Statistical analysis}

Statistical data expressed as means \pm standard error were obtained from the $(n=5)$ separate experiments. The averages calculated were compared from Student's test $(\mathrm{t})$. When $\mathrm{p} \leq 0.05$, the difference is said to be significant. The curves and statistical analysis were performed using Graph Pad Prism 6. San Diego, CA, USA. 


\section{Results}

\subsection{Acute toxicity study by gavage}

The results of the acute gavage toxicity study in mice showed no deaths, with doses of 100, 1000, 3000, $4000 \mathrm{and} 5000 \mathrm{mg} / \mathrm{Kg}$ bw of the aqueous extract of Saba senegalensis. All animals were observed over 14 days. The LD50 of the aqueous extract of Saba senegalensis was greater than $5000 \mathrm{mg} / \mathrm{Kg}$ bw.

\subsection{Evaluation of the hypoglycaemic activity of the aqueous extract of Saba senegalensis in normo-glycaemic mice}

Figure 1, shows the blood glucose value in the presence of Saba senegalensis at increasing concentration or glibenclamide at $10 \mathrm{mg} / \mathrm{Kg}$ bw, in normo-glycemic mice. Saba senegalensis causes dose-dependent hypoglycemia usually followed by an increase in blood glucose. Glibenclamide causes a continuously progressive hypoglycemia which is $48.94 \%$ ( $\mathrm{P}<0.001)$ after 2 hours. Table 1 , represents the Change in blood glucose levels in normo-glycemic mice in the presence of aqueous extract of Saba senegalensis at increasing concentration and, glibenclamide at $10 \mathrm{mg} / \mathrm{Kg}$ bw. The aqueous extract of Saba Senegalensis at $75-200 \mathrm{mg} / \mathrm{Kg}$ bw causes a dose-dependent decrease in blood glucose levels ranging from 4.84-34.62\% ( $\mathrm{P}<0.01-0.05$ ), 60 minutes after treatment. Immediately, blood glucose levels rise to normal. At $250 \mathrm{mg} / \mathrm{Kg}$ bw, the aqueous extract of Saba Senegalensis causes prolonged hypoglycemia similar to that induced by glibenclamide. This hypoglycemia is $39.21 \%(\mathrm{P}<0.001)$ after two hours.

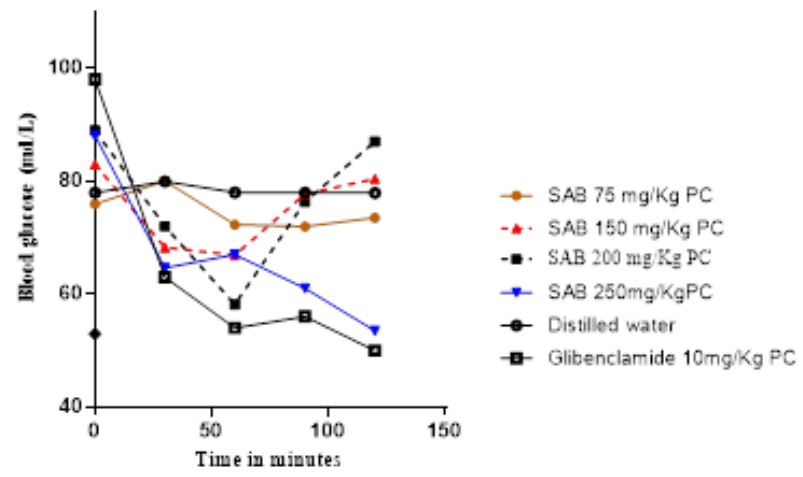

Fig. 1: Blood Glucose Values in Normoglycemic Mice in the Presence of Aqueous Extract of Saba Senegalensis at increasing Concentration.

Table 1: Change in Blood Glucose Levels in Normoglycemic Mice in the Presence of Aqueous Extract of Saba Senegalensis at Increasing Concentration

\begin{tabular}{|c|c|c|c|c|c|}
\hline \multirow{2}{*}{ Treatments } & & \multicolumn{4}{|c|}{ Percentage (\%) } \\
\hline & & 30 min. & $60 \mathrm{~min}$. & $90 \mathrm{~min}$. & 120 \\
\hline \multirow{4}{*}{ Saba senegalensis $\mathrm{mg} / \mathrm{Kg} \mathrm{PC}$} & 75 & +5.35 & -4.84 & -5.26 & -3.24 \\
\hline & 150 & $-17.73^{*}$ & $-19.34 *$ & -6.34 & -3.13 \\
\hline & 200 & $-19.08^{*}$ & $-34.62 * *$ & -14.22 & -2.22 \\
\hline & 250 & $-26.56^{*}$ & $-23.91 *$ & $-30.67 * *$ & $-39.21 * *$ \\
\hline Distilled water & & +2.49 & +0.01 & -0.03 & -0.05 \\
\hline Glibenclamide $\mathrm{mg} / \mathrm{Kg}$ PC & 10 & $-35.69 * *$ & $-44.87 * *$ & $-42.81 * *$ & $-48.94 * * *$ \\
\hline
\end{tabular}

\subsection{Evaluation of the anti-hyperglycemic activity of the aqueous extract of Saba senegalensis in mice temporarily hyperglycemic (HGPO test)}

Figure 2, shows the blood glucose in mice temporality turned hyperglycemic in the presence of Saba senegalensis at increasing concentration or glibenclamide at $10 \mathrm{mg} / \mathrm{Kg}$ bw. Saba senegalensis at concentrations between 75 and $250 \mathrm{mg} / \mathrm{Kg}$ bw, has a dose-dependent antihyperglycemic effect resulting in a lowering of the hyperglycemic peak ranging from 26.49 to $71.77 \%$ ( $\mathrm{p}<0.01-0.001$ ). As shown in Table 2, the aqueous extract of Saba senegalensis at concentrations between 75 and $250 \mathrm{mg} / \mathrm{Kg}$ bw, results in a dose-dependent reduction of glucose-induced hyperglycaemia at a dose of $3 \mathrm{~g} / \mathrm{Kg}$ bw. This reduction ranges from 48.60 to $81.84 \%(\mathrm{P}<0.05)$ after one hour, for a concentration of Saba senegalensis ranging from 75 to $250 \mathrm{mg} / \mathrm{Kg}$ bw. On the other hand, the increase in blood glucose is $8.04 \%$ in the presence of glibenclamide, a $91.96 \%$ decrease in hyperglycemia induced by glucose overload one hour after treatment.

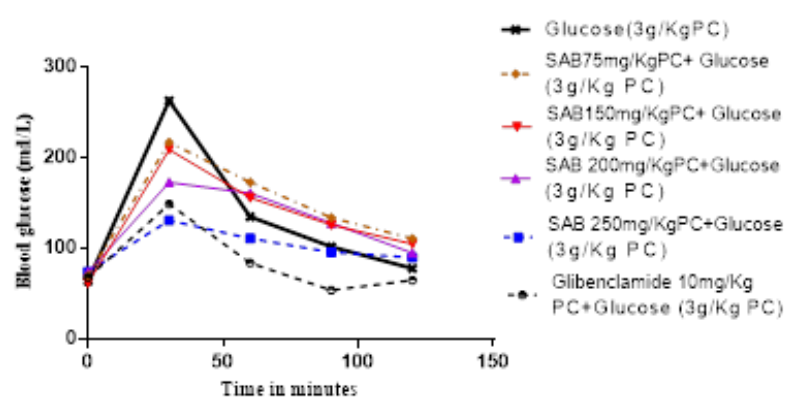

Fig. 1: Blood Glucose Values in Mice Temporarily Turned Hyperglycemic in the Presence of Aqueous Extract of Saba Senegalensis at Increasing Concentration. 
Table 2: Change in Blood Glucose Levels in Mice Temporarily Turned Hyperglycemic in the Presence of Aqueous Extract of Saba Senegalensis at Increasing Concentration

\begin{tabular}{|c|c|c|c|c|c|}
\hline \multirow{2}{*}{ Treatments } & & \multicolumn{4}{|c|}{ Percentage $(\%)$} \\
\hline & & 30 min. & $60 \mathrm{~min}$. & $90 \mathrm{~min}$. & 120 \\
\hline \multirow{4}{*}{ Saba senegalensis $\mathrm{mg} / \mathrm{Kg} \mathrm{PC}$} & 75 & $+73.51 *$ & +51.40 & +31.98 & +20.54 \\
\hline & 150 & $+71.85^{*}$ & +47.29 & +31.89 & +20.49 \\
\hline & 200 & $+49.74 * *$ & +43.69 & +27.42 & +11.00 \\
\hline & 250 & $+28.23 * * *$ & $+18.16^{*}$ & +10.62 & +7.61 \\
\hline Distilled water & & +2.49 & +100 & +35.66 & +19.08 \\
\hline Glibenclamide $\mathrm{mg} / \mathrm{Kg} \mathrm{PC}$ & 10 & $+40.70 * * *$ & $+8.04 * *$ & $-7.03 *$ & -1.50 \\
\hline
\end{tabular}

\section{Discussion}

The objective of this study is to evaluate the hypoglycemic and anti-hyperglycemic effects of the aqueous extract of Saba senegalensis. In normoglycemic mice, the aqueous extract of Saba senegalensis from 75 to $250 \mathrm{mg} / \mathrm{Kg}$ bw causes a dose-dependent reduction of blood sugar levels ranging from 4.84 to $34.62 \%, 60$ minutes after treatment. Immediately, the glycemia increases to reach the normal value for concentrations of Saba senegalensis lower than $200 \mathrm{mg} / \mathrm{Kg}$ bw. Glibenclamide $10 \mathrm{mg} / \mathrm{Kg}$ bw, $48.94 \%$ drop in blood sugar after one hour of treatment. These results indicate that, the aqueous extract of Saba senegalensis, like glibenclamide, has a hypoglycemic effect in normoglycemic mice. These hypoglycemic effects are also observed in other plants, in particular RauvolFia vomitoria afzel and Anabasis atrticula (N'Doua et al., 2015, Kambouche et al., 2009)

Glibenclamide induces this hypoglycemic effect by inducing the production of insulin by the pancreas, and by activating the peripheral consumption of glucose. This hypoglycemic effect is prolonged in certain patients, especially the elderly (Talbert et al., 2009). The aqueous extract of Saba senegalensis could act according to this mechanism. In other words, the aqueous extract of this plant like Anabasis articula (Kambouche et al., 2009) would contain insulin-releasing and/or insulin-like substances, capable directly or indirectly of inducing hypoglycemia. This effect is dose-dependent since for concentrations below $200 \mathrm{mg} / \mathrm{Kg}$ bw, the hypoglycaemic effect of Saba senegalensis less prolonged.

The test for hyperglycemia induced by oral glucose (3g/Kg bw) administration (OPGH), in the presence of aqueous extract of Saba senegalensis, shows a dose-dependent reduction of the hyperglycemic peak induced by glucose overload at $3 \mathrm{~g} / \mathrm{Kg}$ bw. This anti-hyperglycemic effect of the aqueous extract of Saba senegalensis, recalls that of glibenclamide. Like this reference antidiabetic molecule, the aqueous extract of Saba senegalensis could promote the entry and oxidation of glucose in these peripheral cells. It can also be considered, the decrease of intestinal glucose absorption, of its bioavailability in the presence of the aqueous extract of Saba senegalensis, as would be the case with epicatechin gallate and migitol, an oral antidiabetic (Shimizu et al., 2000, Ovaskainen et al., 2008). The anti-hyperglycemic and hupoglycemic effects of Saba senegalensis are reminiscent of those of many plants including Zizyphus mauritiania, Zizuphus micronata and anacardium occidentalis (Dénoue et al., 2016, Singh, 2010). The hypoglycemic and anti-hyperglycemic effects of Saba senegalensis can be attributed to tannins and other compounds including saponosides and flavonoids (SARR et al., 2015). The toxicological results of this plant indicate that it is non-toxic, especially since its lethal dose, $\mathrm{LD}_{50}$ is greater than $5 \mathrm{~g} / \mathrm{Kg}$ bw (Clarke, 1997).

\section{Conclusion}

The present study attests that Saba senegalensis possesses hypoglycemic and antihyperglycemic properties, probably linked to the presence in the aqueous extract of this plant of insulin-like or and insulin-releasing substances that remain to be determined. The aqueous extract of Saba senegalensis, protects against prolonged hypoglycemia, except for high concentrations. These data justify, that this non-toxic plant is potentially antidiabetic; it could therefore contribute to the fight against diabetes in traditional medicine.

\section{References}

[1] American Diabetes Association (2002). Screening for Diabetes. Diabetes. Care 4 (25) Supplement1 : S21-S24 https://doi.org/10.2337/diacare.25.2007.S21.

[2] Dénou A, Sawadogo Y, Haïdara M. Togola A.Sanogo R. Diallo D(2016). Activité antidiabétique des racines de Zizyphus mauritiana Lam (Rhamnaceae) et des feuilles de Zizyphus mucronataWilld chez le lapin. Int. J. Multidiscip. Res. Dev. 3(6) :24-26 http://www.allsubjectjournal.com/ doi.org/10.22271/ijmrd.

[3] Kambouche N, Merah B, Derdour A., Bellahouel S., Younos C., Soulimanl R (2011). Activité antihyperglycémiante d'un stérol $\beta$-sitoglucoside isolé de la plante Anabasis articula (Forssk) Moq. Phytothérapie 9 : 2-6 https://doi.org/10.1007/s10298-010-0603-4.

[4] Marles JR, Fransworth NR (1994). Plants as sources of antidiabetic agents. Econ Med Plant Res (6) : 150-85.

[5] N'Doua L A. R, Abo K.J.C, Aoussi S. Gbogbo M. Yapo A.P. Ehile E.E. (2015) Effets hypoglycémique et antihyperglycémique de l'extrait 70\% de racines de Raufolvia vomitoria afzel (Apocyanaceae). European Scientific Journal 11(6) : 176-190. https://eujournal.org/index.php/esj/article/viewFil.

[6] Arbonnier M (2002). Arbres, arbuste et lianes des zones sèches de l'Afrique de l'ouest. $2^{\text {nd }}$ Ed CIRAD-France $573 \mathrm{p}$.

[7] SARR M.G, Ndiaye N.D, Ayessou N.C, Faye P.G, Cisse M. Sakho (2018) M. Saba senegalensis : Key features and Use. Food and Nutrition Sciences (9) : 1099-1111 https://www.scirp.org/Journa https://doi.org/10.4236/fns.2018.99080.

[8] Eklu-Natey RD, Balet A. (2018) Pharmacopée Africaine. Dictionnaire et Monographies Multilingues du potentiel Médicinal des plantes Africaines. Afrique de l'Ouest Edition d'en bas- traditions et Médecine TM : Genève volume 2.

[9] SARR OR, Fall AD, Gueye R. Diop F. Sene B. Diatta K. (2015) Evaluation de l'activité antioxydante des feuilles de Alpinia senegalensis (Sapindaceae) et de Saba senegalensis (Apocyanaceae). Int. J. Biol. Chem. Sci 9(6) : 2676-2684 https://www.ajol.info/index.php/ijbcs/article/view https://doi.org/10.4314/ijbcs.v9i6.13.

[10] Magassouba F.B., Dialo A., Kouyaté M., Mara F. Mara O. Bangoura A. (2007) Ethnobotanical survey and antibacterial activity of some plants used in Guinean traditional medicine. J Etnopharmacol 144 :44-53. https://doi.org/10.1016/j.jep.2007.07.009.

[11] Traore A, Ouedraogo S, Lompo M, Traoré S, Some N, Guissou IP. (2013) Ethnobotanical survey of medicinal plants used to treat gastrointestinal parasites in humain and livestock in four geographics areas of Burkina Faso (west Africa). Arch Appl Sci Res 5(6): 172-7. https://www.semanticscholar.org/paper/Ethnobotanical-survey-of-medicinal-plants-used-to-t-Traoré-Ouédraogo/. 
[12] Boamponsem GA, Johnson FS, Mahunu GK. Awiniboya S.F. (2013) Détermination of biochemical composition of Saba senegalensis (Saba fruit). Asian Journal of plant science and Research. 3(1):31-36 https://www.imedpub.com/articles.

[13] Masunda T.A, Mbala M.B, Kayembe S.J., Longoma B.F., Ngbolua K.N., Tshibangu D.S.T. et al. (2014) Activité anti-hyperglycémique et antiradicalaire des extraits des fruits de Raphia gentilina de Wild (Arecaceae).Int.J.Biol.Chem.Sci 8(6):2441-2451 https://www.ajol.info/index.php/ijbcs/article/view/. https://doi.org/10.4314/ijbcs.v8i6.7.

[14] Kambouche N, Merah B, Derdour A. Bellahouel M.M, Benziane C,Younos M., et al. (2009) Etude de l'effet antidiabétique des saponines extradites d'Anabasis articula (Forssk) Moq, plante utilisée traditionnellement en Algérie. Phytothérapie 7: 197-201 · https://www.semanticscholar.org/paper/ https://doi.org/10.4314/ijbcs.v8i6.7.

[15] Talbert M, Willoquet G, Gervais R. (2009) Le guide pharmaco clinique. Wolter Kluwer France $1090 \mathrm{p}$

[16] Shimizu M, Kobayashi Y, Suzuki M. Satsu H. Miyamoto Y. (2000) Regulation of intestinal glucose transport by tea catechins. Biofactors 13 : 6165. https://www.researchgate.net/publication/. https://doi.org/10.1002/biof.5520130111.

[17] Ovaskainen ML, Torronen R, Koponen JM, Sinkko H, Hellstrom J, Reinvuo H, et al. (2008) Dietary intake and major food sources of polyphenols in finish adults. J. Mol. Sci 138 : 562-80 https://www.ncbi.nlm.nih.gov/pubmed/. https://doi.org/10.1093/jn/138.3.562.

[18] Singh R. (2010) Antihyperglycemic effect of ethanolic extract and fractions of Anacardium Occidentale L. stem bark in streptozotocin-induced diabetic rat. Journal of Basic and Clinical Pharmacy 1(1):16-19.

[19] https://www.ncbi.nlm.nih.gov/pmc/articles/PMC4158895/pdf/JBCP-1-16.pdf.

[20] Clarke E.G.C, Clarke M.L. (1997) Veterinary Toxicology. Cassel and Colier Macmillan Publishers, London; pp268-277. 